\title{
A GENERALIZED ČEBYŠEV FUNCTIONAL FOR THE RIEMANN-STIELTJES INTEGRAL
}

\author{
S. S. DRAGOMIR
}

Abstract. Sharp bounds for a generalised Čebyšev functional for the Riemann-Stieltjes integral are given.

Mathematics subject classification (2010): Primary 26D15; Secondary 26D10.

Keywords and phrases: Čebyšev functional, Grüss type inequality, Riemann-Stieltjes integral.

\section{REFERENCES}

[1] R. P. Agarwal AND S. S. DRagomir, A survey of Jensen type inequalities for functions of selfadjoint operators in Hilbert spaces, Comput. Math. Appl. 59 (2010), no. 12, 3785-3812.

[2] T. M. Apostol, Mathematical Analysis, Second Edition, Addison-Wesley Publishing Comp. Inc., 1975.

[3] P. Cerone And S. S. Dragomir, New bounds for the Čebyšev functional, App. Math. Lett., 18 (2005), 603-611.

[4] P. Cerone And S. S. Dragomir, A refinement of the Grüss inequality and applications, Tamkang J. Math. 38 (2007), No. 1, 37-49. Preprint RGMIA Res. Rep. Coll., 5 (2) (2002), Art. 14. [online http://rgmia.vu.edu.au/v8n2.html].

[5] P. L. Chebyshev, Sur les expressions approximatives des intègrals dèfinis par les outres prises entre les même limites, Proc. Math. Soc. Charkov, 2 (1882), 93-98.

[6] X.-L. Cheng And J. Sun, Note on the perturbed trapezoid inequality, J. Ineq. Pure \& Appl. Math., 3 (2) (2002), Art. 29. [online http://jipam.vu.edu.au/article.php?sid=181].

[7] S. S. DRAGOMIR, A generalization of Grüss's inequality in inner product spaces and applications, J. Math. Anal. Appl. 237 (1999), no. 1, 74-82

[8] S. S. DraGOMIR, On the Ostrowski's inequality for Riemann-Stieltjes integral and applications, Korean J. Comput. \& Appl. Math., 7 (3) (2000), 611-627.

[9] S. S. Dragomir, Some inequalities for Riemann-Stieltjes integral and applications, Optimisation and Related Topics, Editor: A. Rubinov, Kluwer Academic Publishers, (2000), 197-235.

[10] S. S. DRAGOMIR, Some inequalities of midpoint and trapezoid type for the Riemann-Stieltjes integral, Nonlinear Analysis, 47 (4) (2001), 2333-2340.

[11] S. S. Dragomir, On the Ostrowski inequality for Riemann-Stieltjes integral where fis of Hölder type and $u$ is of bounded variation and applications, J. KSIAM, 5 (1) (2001), 35-45.

[12] S. S. DRAGOMIR, Sharp bounds of Čebyšev functional for Stieltjes integrals and applications, Bull. Austral. Math. Soc. 67 (2) (2003), 257-266.

[13] S. S. DraGOMIR, New estimates of the Čebyšev functional for Stieltjes integrals and applications, J. Korean Math. Soc., 41 (2) (2004), 249-264.

[14] S. S. DRAGOMIR, On the Ostrowski inequality for the Riemann-Stieltjes integral $\int_{a}^{b} f(t) d u(t)$, where $f$ is of Hölder type and $u$ is of bounded variation and applications, J. KSIAM, 5 (2001), No. 1, 35-45.

[15] S. S. DRAGOMIR, Approximating the Riemann-Stieltjes integral by a trapezoidal quadrature rule with applications, Mathematical and Computer Modelling 54 (2011), 243-260.

[16] S. S. DRAGOMIR AND J. SÁNDOR, The Chebyshev inequality in pre-Hilbertian spaces, I, Proceedings of the Second Symposium of Mathematics and its Applications (Timişoara, 1987), 61-64, Res. Centre, Acad. SR Romania, Timişoara, 1988. MR1006000 (90k:46048). 
[17] S. S. DRAGOMIR, J. PEČARIĆ AND J. SÁNDOR, The Chebyshev inequality in pre-Hilbertian spaces, II, Proceedings of the Third Symposium of Mathematics and its Applications (Timişoara, 1989), 7578, Rom. Acad., Timişoara, 1990. MR1266442 (94m:46033).

[18] S. S. DrAgomir, J. E. PeČARIĆ AND B. TePeš, Pre-Grüss type inequalities in inner product spaces, Nonlinear Funct. Anal. Appl. 9 (2004), no. 4, 627-639.

[19] G. GRÜSs, Über das Maximum des absoluten Betrages von $\frac{1}{b-a} \int_{a}^{b} f(x) g(x) d x-\frac{1}{(b-a)^{2}} \int_{a}^{b} f(x) d x$ $\int_{a}^{b} g(x) d x$, Math. Z., 39 (1935), 215-226.

[20] X. Li, R. N. Mohapatra And R. S. Rodriguez, Grüss-type inequalities, J. Math. Anal. Appl. 267 (2002), no. 2, 434-443.

[21] Z. LIU, Refinement of an inequality of Grüss type for Riemann-Stieltjes integral, Soochow J. Math., 30 (4) (2004), 483-489.

[22] A. LuPAŞ, The best constant in an integral inequality, Mathematica (Cluj, Romania), 15 (38) (2) (1973), 219-222.

[23] D. S. Mitrinović, J. E. PeČArić And A. M. Fink, Classical and New Inequalities in Analysis, Mathematics and its Applications, (East European Series), 61. Kluwer Academic Publishers Group, Dordrecht, 1993.

[24] A. MCD. Mercer, An improvement of the Grüss inequality, J. Inequal. Pure Appl. Math. 6 (2005), no. 4, Article 93, 4 pp. (electronic).

[25] A. M. Ostrowski, On an integral inequality, Aequat. Math., 4 (1970), 358-373.

[26] B. G. PAChPatte, On Grüss like integral inequalities via Pompeiu's mean value theorem, J. Inequal. Pure Appl. Math. 6 (2005), no. 3, Article 82, 5 pp. (electronic).

[27] J. Pečarić, F. Proschan and Y. L. Tong, Convex Functions, Partial Orderings, and Statistical Applications, Academic Press Inc., 1992. 